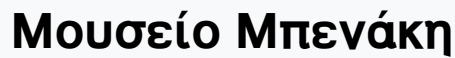

A Singular Antiquity: Archaeology and Hellenic Identity in Twentieth-Century Greece

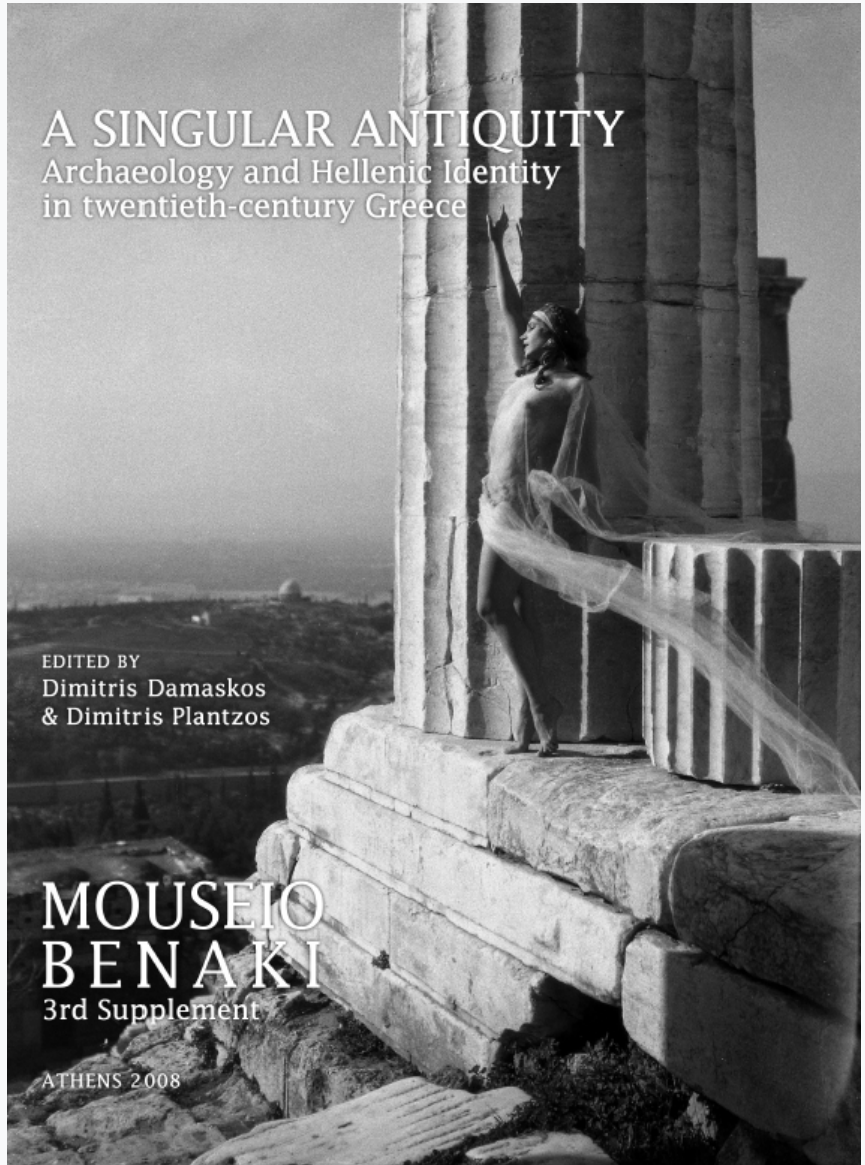

In place of a conclusion

Dimitris Damaskos

doi: $10.12681 /$ benaki.18067

Copyright $\odot$ 2018, Dimitris Damaskos

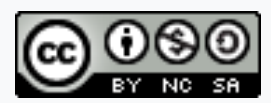

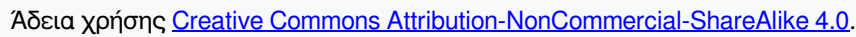

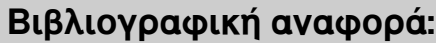

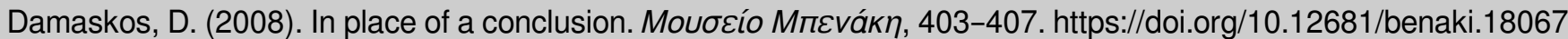


AFTERWORD 



\section{In place of a conclusion}

MANY OF THE PAPERS in this volume come from the Conference entitled 'Antiquity, Archaeology and Greekness in twentieth-century Greece', organized by the Benaki Museum in January 2007. This was the first concerted attempt to explore how archaeology, and indeed antiquity, had affected the formation of a national identity in Greece in the twentieth century, when the forged continuity of Greek civilization from the ancient era until the modern day was a given in Greek society and the state itself. The conclusions which have come from the process of organizing this conference, and from studying the papers in this book, correspond to the questions posed before the conference itself took place.

Antiquities were integrated in a variety of ways into this schema of unbroken continuity, a notion first shaped in the nineteenth century by Paparrigopoulos and maintained ever since by virtually all Greeks - both promoted by important intellectual figures (Tolias) and collectively endorsed in the post-war years by the conservatives as much as by the Left (Koufou). Taking care of ancient monuments was central to the 'hellenization' of the recently constructed state and the consolidation of its historical origins. The antiquities offered a means of defending the national interests at any given time (Mazower), through state-run and sponsored excavations, new museum displays and temporary exhibitions at home and (mostly) abroad (Gazi, Mouliou and Voudouri), and large excavation projects entrusted to foreign archaeological schools (Sakka). Hellenic continuity is represented in linear fashion, without any lapses or breaks up to the present day even in modern multimedia applications of an educational or recreational nature (Tzortzaki).
It is consequently only to be expected that archaeology in Greece should align itself with the main ideological and cultural axes of the nation. Good examples of this can be found in the method of teaching archaeology at Greek universities (Karamanolakis) and in the inclusion of (preGreek) prehistory and the so-called 'post-Byzantine' (i.e. Ottoman) period in Paparrigopoulos' tripartite scheme (Kotsakis and Mourelatos). At the same time the state was at a loss as to how to manage monuments, which were hard to fit into Paparrigopoulos' concoction (Gratziou and Hamilakis). The ancient sources were instrumental in the creation of the discipline and in forming its ideological programme (Bounia), as was the epistemological example (rooted in Romanticism) of philology (Calotychos). The linear reading of ancient art helped to establish a 'safe' - and ethnically advantageous - narrative about Greek civilization (Plantzos).

Antiquity was also a strong presence in the shaping of the Greek identity: writers sought the identifying marks of Greekness in it (Lambropoulos, Tziovas and Diamandi); artists gave it pride of place in the construction of an aesthetic Greekness, which they were promoting as the answer to Modernism (Hamalidi); while antiquarians of all kinds were turning to the past in their efforts to rein modernity in (Damaskos). Thus antiquity was a central feature in designing national festivals and anniversaries (Markatou) as well as in shaping modern Greek architecture (Philippides), mostly public but also private, the latter claiming, in its turn, a role in shaping the Greek identity (Herzfeld). Finally, it was a source of inspiration and a starting point for aesthetic and cultural explorations in non-Greek contexts (Leontis). 
Looking back at the history of Greece in the twentieth century one is aware just how much the central theme of this book affected the whole cultural and even political life in Greece. A good example is the ideological ferment of the generation of the thirties who, in their attempt to rebuild and boost morale (shattered by the Asia Minor Catastrophe) went back to the past in their search for a continuous Greek identity, bolstering Paparrigopoulos' scheme and the manifold expressions of the concept of national continuity.

But these kinds of explorations did not end there, but have continued, with fluctuating intensity, ever since. Towards the end of the twentieth century indeed Greece was trying to define its position in a constantly changing Europe after the break-up of the Eastern bloc and the change in the balance between the world powers. The search for a Greek identity came up again with the 'Macedonian question'. The break-up of Yugoslavia and its separation into more or less ethnic states triggered introverted reactions in the Greek community, which felt itself threatened by the southernmost republic of old Yugoslavia claiming the right to self-determination under the name of Macedonia. Reactions were not just confined to the huge demonstrations in Greece and abroad about the 'name', regardless of whether or not these were the main form of response, or to the skirmishes (mainly in newspapers) between the opposing sides. Archaeology contributed to the campaign with exhibitions relating to ancient Macedonia, aimed at 'sensitizing' the public abroad to the issue, using the antiquities excavated in Northern Greece. The finds themselves were pressed into the service of 'national policy', with the help of a host of state-sponsored archaeological digs in Northern Greece in recent decades.

In both periods, in the post-war years and in the nineties, Greece maintained a defensive and inward-looking attitude towards the changes going on around it, attempting to shelter behind issues of identity, using antiquity or folk culture to achieve or defend its aims. However, while the search to define the Greek identity in the years after the Asia Minor Catastrophe can be explained and understood historically in the context not just of Greek but of European post-war history, the recent struggles over Macedonia are more difficult to comprehend, unless the equivocal role of archaeology in the shaping of Greek identity is also underlined.

The preoccupation with archaeological matters in Greece shows the direction taken by the discipline of ar- chaeology, as it developed in Greece. Choosing an inwardlooking and conservative path, Greek archaeology seemed content with the role of guardian of national ideology, conferred on it by the Greek state. Archaeology in Greece, throughout its career to date, has been an archaeology of Greece, with its main concern being to explore the historical past of the Greek state and, with the help of folklore, to ascertain the continuity, unmediated and unbroken, of Hellenism. The aim in the first place was to create a centuries-old national past, in order to justify the need for a liberated Greece to the European world of the nineteenth century, something which continued subsequently, when there was no reason to doubt its sovereignty. To that end its inhabitants had to be of pure Greek descent, without any miscegenation from other neighbouring and often hostile races which might be working towards the same ends (e.g. Bulgarians, Slavs, Albanians). The hellenization of proper names and place-names was undertaken in a similar spirit, often with amusing results. A consequence of this policy was the creation of a mythical past, which modern Greeks share in as direct and sole descendants of the ancients, a sort of 'national treasure' which gave the people of that nation a self evident right to customize the past, whatever that entailed for the country's leading lights - whether archaeologists or otherwise - and their approach to the past.

Certain characteristic examples show just how much this relationship has influenced the thinking and attitudes of Greek society. It is not considered strange that the Acropolis is referred to as the 'Holy Rock', as if the Olympian gods were still at the heart of religion in Greece. Similarly it is not thought strange that the Greek government should declare its intention to demolish anything which stands between the so-called 'Holy Rock' and the new Acropolis Museum. And it proposes to do this not because the buildings, about which a great deal has been written to date, some of it in this present volume (Introduction and Tziovas), obstruct the view of the Theatre of Dionysos, but because maintaining the 'purity' of the archaeological site means purging anything which interrupts the line between antiquity and the present day. To this end the so-called 'Holy Rock' has - in the not so distant past - been purged of anything which was not ancient or Classical Greek. Moreover it is not seen as strange that Roman, Frankish and Ottoman times are perceived as periods of servitude and decline, while the Byzantine period is eminently 'Hellenic'; or in other words that we speak of 
'Turkish domination' (tourkokratia) and 'Frankish domination' (frangokratia) but that there is no such thing as byzantinokratia - 'Byzantine domination'. It is difficult to fit anything foreign into the course of Greek civilization, as described in obsolete school textbooks and ideological narratives: the Greek people has gone through the ages passing on knowledge and anything which is not part of this is automatically hellenized. Finally it is not strange that the section in the Benaki Museum devoted to Islamic Art has a problem attracting visitors. Greeks identify the Islamic culture of the past with the Ottoman 'oppression', which enslaved the nation. And therefore they argue: Why should we make any attempt to get to know about it?

Antiquity continues to this day to be the high point in the history of Greek civilization. And Greeks learnt at school that they were the sole heirs to it, the ones really entitled to manage its remains ('our antiquities' or 'our Parthenon marbles'). This explains why the slogan which predominated in the huge demonstrations in the nineties over the Macedonian question was the inward-looking 'Macedonia is Greek': because the journey from antiquity to the present has no breaks but only continuity, because the development of history and its civilizations is a closed system of enduring values, unadulterated by otherness. Indeed the fact that all Greeks believe that the so-called 'star of Vergina' is an ancient Macedonian symbol, when it has been demonstrated to be something originating in the Orient which was simply used by the Macedonians, has never transcended the confines of the archaeological academy.

From reading this book one comes to an unsurprising conclusion: that Greek society's contacts with the past are emotive, prioritizing an aesthetic veneration of the past as 'art' and of Greekness as 'landscape' and not something historical or ultimately political - which accounts for the fondness for using the past and/or archaeology in 'national issues'. The result is that anyone outside Greece following debates about 'national (i.e. Greek) issues' will not understand the arguments which have gone before, as was demonstrated by the recent experience of trying to put across the so-called 'Macedonian question' abroad.

And to return to the generation of the thirties: the fact that virtually all the Greek intelligentsia aligned themselves with the Metaxan ideology does not appear to have especially daunted subsequent generations, regardless of their political leanings, who turned a blind eye, given that a belief in the continuity of Greek civilization was the main point at issue. In this context one can understand why the Greek light of Elytis, Theotokas and others, is still thought of as the grit in the oyster which helped to produce the so-called 'Greek miracle'.

This albeit very brief description of the status of archaeology in Greece sets out the framework in which the discipline of archaeology developed in Greece in the twentieth century, at the same time as posing the urgent question: how can we continue to study antiquity in an age when classical studies worldwide are being obliged to regroup? Is the connection between archaeology and support for a blind belief in Greekness the appropriate way for the discipline to go in the twenty-first century?

Archaeology's attitude to academic developments in recent decades seems problematic. For example, the no longer quite so new philosophical achievements have become commonplace in theoretical sciences all over the world, yet archaeology in Greece systematically ignores the advantages it could get from developing, for example, cultural studies or the possibility of applying some of its findings to Greek issues. Archaeology is hermetically sealed against intercultural subjects, which could put Greek archaeology and the ancient Greek civilization in a dialogue with other cultures. And this dialogue is not only about how the archaeological community addresses academic issues, but is about getting it into the community with all its ideological and political concerns.

To what extent imposing a Greek identity (whether obligatory or not) was the appropriate way to achieve national goals is not something which can be gone into in any detail here. But times are changing - and rapidly. The Greek government has no need of inward-looking or defensive policies on matters of cultural identity. On the contrary, at a time when it is an everyday event to find populations moving around and rubbing shoulders not just with neighbours but with people from whom they were once separated by vast distances, in a constantly changing ethnic and cultural landscape where multiculturalism becomes commonplace, a tendency is emerging which positions archaeology firmly in contemporary Greek reality. This reality is to a large extent defined in the bigger urban centres by the great wave of immigrants, legal or otherwise, from Eastern Europe, Asia and Africa. How can the new migrants integrate into the modern social fabric of Greece when the education authorities and other powers that be continue to view Greek society as a 


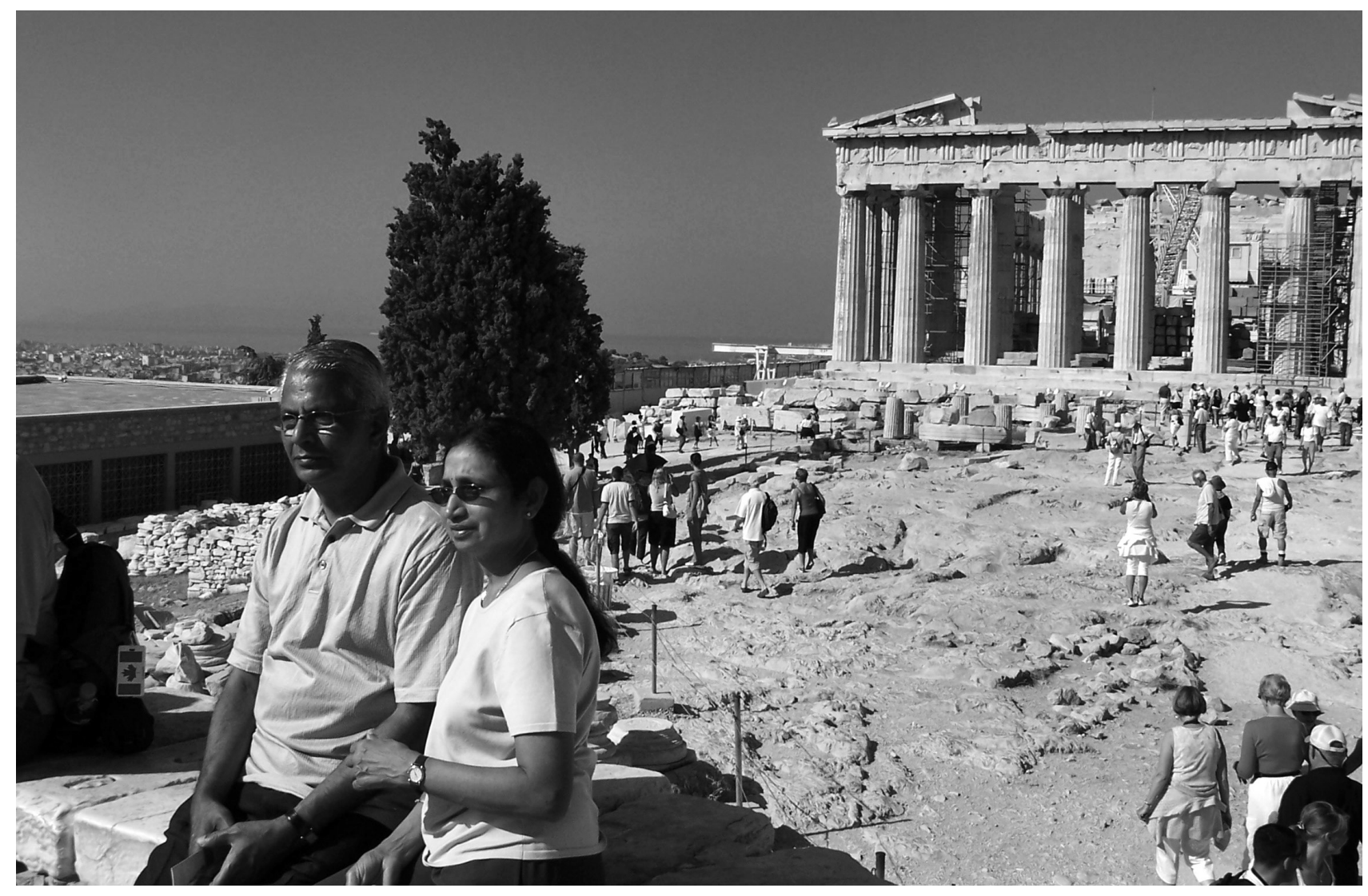

Fig. 1. Indian visitors in front of the Parthenon (photo: author).

homogenous social, ethnic and religious entity? (A typical example is the complete identification of the Greek nation with Orthodoxy). Why therefore do we insist on linear continuity rather than partly superimposed circles one after another? How can one give the 'new' Greeks the feeling of participating in the country where, like it or not, they have chosen to live, when that country's past is literally untouchable? In such a situation the past can either be viewed with indifference or with the mentality of the tourist, who has a photo taken on the Acropolis because - according to the international rules of a global lifestyle $-\mathrm{a}$ visit to the Parthenon is one of the 50 items on the list of 'things to do before you die' (fig. 1). If a foreigner resident in Greece regards the material remains of the past with indifference, that indifference can easily become hostility to the unfamiliar - and if we are completely realistic, this is exactly the attitude of most Greeks to the material remains of their otherwise glorious past.

But it is not only the question of how multicultural
Greek society is today. The business of introducing young people to antiquity and classical studies in general is preoccupying the academic community, which often feels it is not getting through in an age of rapid data transfer over the internet and a global pop culture. How can the past and its remains be integrated into modern society with its information overload, when the study of the past seems outmoded and disconnected from modern reality?

If 'Greekness' was once really the only way for the Greek state - and consequently for archaeology - to justify an important ideological and political tactic, unhitching itself from the chariot of Greekness and turning to a more 'multicultural' policy looks like the solution to the isolation which may otherwise be in store for Greek archaeology in future. If this can be done without throwing out the ideological tactics used to maintain certain positions in the recent past, it would perhaps be better to think that an opening out of archaeology's epistemological horizons can go hand in hand with the expansion of the community, 
both in Greece and globally, in which the discipline is developing. This possibility presupposes distancing ourselves from the inward-looking tactics resorted to in the past.

Opening itself up to associated disciplines - and not only those concerned with antiquity - can put the discipline in the front line of interdisciplinary discussions, given the constant interest of scholars in studying the past in order to explore and achieve a deeper understanding of individual and group identities.

Finally adapting archaeology to the new socio-political circumstances of the twenty-first century obliges it to accept its global relevance beyond the narrow limits of a nation state and to promote a discipline which will stress the importance of Greek culture worldwide and not just the narrow, parochial and/or nationalistic approach. It is arguably imperative from now on to rethink archaeology and the ideological approach to the past through an archaeology free from the academic and ideological burden of modernism and - above all - the political choices of the twentieth century, which have preserved and perpetuated the obsessions and the dead-ends of the nineteenth century. Ideally this will be a discipline which will accept that its first duty is to give equal treatment in terms of pro- tection, management and promotion to all cultural assets on Greek soil, of whatever national or ethnic identity, and not to draw up a national ideological programme based on ancient monuments. (In this respect the announcement of the President of the Organization for the Construction of the New Acropolis Museum in Kathimerini's Kmagazine on 5 August 2007 is striking: the Museum, it seems, is being built to back up Greek demands for the return of the Parthenon Marbles and not because the sculptures in the small museum on the Acropolis needed a museum worthy of their importance. It will only be when our antiquities cease to be seen as a national legacy in the communal subconscious that they will no longer constitute, in the eyes of many, an 'encumbrance' in developing a contemporary Greek culture. Only by escaping the suffocating embrace of nationalism can our singular antiquities indeed become global cultural property.

Dimitris Damaskos

Department of Cultural Heritage Management and New Technologies

University of Ioannina

ddamaskos@yahoo.com 
